Review scientific article Received 05.11.2017.

Approved 31.03.2018.

\title{
THE BELT AND ROAD INITIATIVE: INFRASTRUCTURE, INVESTMENTS AND OPPORTUNITIES FOR LATIN AMERICA
}

"The direction of the wind in the world has changed. The wind from the west no longer prevails over the east, but the east wind prevails over the west" (Mao Tse Tung, Moscow, November 17, 1957).

The Belt and Road Initiative proposed by China in 2013 is without a doubt the most ambitious connectivity project of modern times. The implications in terms of trade, cultural exchanges, infrastructure building and development are significant. This paper gives a description of this initiative in its various objectives - not only as the last part of Chinese domestic economic development strategy that started in the eastern regions in the eighties; but also as a geopolitical and international project, highlighting China's new role in the world. Although Latin America is not geographically part of this initiative as it is presented today, this does not mean that the implications and opportunities of this project are not important for the region.

Keywords: Belt and Road Initiative, Latin America, Investments, Xinjiang Autonomous Region, Economic Corridors.

School of Oriental Studies, USAL Buenos Aires, Argentina;

carola.ramon.berjano@hotmail.com 


\section{Introduction}

The initiative known as One Belt One Road (OBOR) is a political and economic initiative launched by China in 2013, whose goal is global in scope and extremely ambitious.

It is referred to as the New Silk Road, alluding to the old route that united East with West through Central Asia and the Middle East. At the time "a belt and a road" was the term chosen to designate this project of great scope. Currently the trend is to call it the Belt and Road Initiative (BRI) Initiative, which is how the author will refer to it in this paper.

A few articles referred to this century as the "Eurasian Century", thus contributing to the Initiative. It is an unprecedented project in terms of connectivity, whether in infrastructure, investment, economics, politics and culture. This project currently involves 65 countries, which account for $66 \%$ of the world's territory, $75 \%$ of the known energy reserves and almost two-thirds of the world's population - about 4,4 billion people. They account for $29 \%$ of the world economy and $25 \%$ of world trade. ${ }^{1}$ Understanding this initiative and reflecting on how it can affect Latin America is therefore crucial. Although Latin America and Argentina in particular are not explicitly included in the initiative, this project affects us as well as the rest of the world economy. On one hand, the immediate effects refer to the greater connectivity between China and its neighbors that belong explicitly to the Initiative. As trade between China and these countries increases, so do the possibilities for Latin American products in order to be replaced by the products of the neighboring countries. The pattern of trade between China and the countries of Central Asia follows a pattern similar to those of Latin America and Africa, i.e. raw materials for manufactured goods. Another immediate effect, which also originates from China's greater exchange with its neighbors, is the emergence of new opportunities along these new routes, with new demands, tastes and preferences, as well as market niches in which Latin American products could find new destinations. Finally, increased links between China and Europe also present Latin America with new opportunities, since an arrival to Asia could occur not only via the Pacific but also via the Atlantic.

On the other hand, and thinking in the mid- and long term, the BRI can benefit Latin America in terms of infrastructure projects. Infrastructure investment is an area that the Latin American region clearly needs. For this, membership in the AIIB (Asian Infrastructure and Investment Bank) is vital. From Latin America, only Brazil belonged to it as a founding member, but now, additional five Latin American countries belong to it as well.

(Peru, Venezuela, Chile, Bolivia and Argentina). Considering all the infrastructure projects in which China has participated or has expressed an

Chin, H. and W.He (2016): The Belt and Road Initiative: 65 Countries and Beyond,Global Sourcing Fung Business Intelligence Centre 
intention to participate, it can be seen that BRI has the potential to be a truly global project. These projects include the railroad across Africa linking Angola, Congo, Zambia and Tanzania; the tunnel project in the Bering Strait; the transAmazonian railway that would link Brazil with Peru; the Canal de Nicaragua, the Kra Canal in Thailand; the high-speed train in Mexico; etc. Some of these projects, although far from being implemented or even approved, show a global connectivity initiative with China as the undisputed protagonist of this new global system. Undoubtedly, more than ever, Latin America needs to identify both short and long term options if it wants to put together a strategy that is mutually beneficial.

\section{What is the Belt and Road Initiative?}

In September 2013, during his speech "Promoting Friendship between Peoples to Create a Better Future" at Nazarbayeb University in Astana, Kazakhstan, Chinese President Xi Jinping first made reference to this new Silk Road, or economic belt, with the aim of strengthening ties between China and Central Asia. Right from the start, the importance and the mention given to the Chinese city of Xi'an - in the center-west of the country - was not random, since this city, which in ancient times had the name of Chang'an was China's imperial capital during 13 dynasties and the starting point of the original silk road. Vestiges of this silk-road can still be seen in the city of Xi'an today, such as the Muslim legacy, with its population, its neighborhood and a great mosque. The choice of Kazakhstan to launch this initiative was not random either, as this Central Asian country along the western Chinese frontier would be a key part of this project. $^{2}$

This first mention of the BRI in Kazakhstan was followed by another one in October 2013, when Chinese President Xi Jinping gave a speech before the Indonesian parliament in which he proposed to strengthen ties between the ASEAN community and China, building a maritime corridor for the new century with the aim of promoting cooperation. Also, during this speech, he proposed the creation of the Asian Infrastructure and Investment Bank (AIIB) to finance infrastructure and interconnectivity projects within the region.

A month later, during the third plenary session of the 18th Central Committee of the Chinese Communist Party, in November 2013, he again mentioned the need to accelerate the construction of infrastructure between neighboring countries in order to facilitate the Belt and Road Initiative. A little over a year later, in March 2015, the National Reform and Development Commission published its "Vision and actions for the joint construction of the belt of the

Ramon-Berjano (2016): La iniciativa "Un cinturón, un camino" y el desarrollo del oeste de China: Impactos domésticos e internacionales, CARI, Documento de Trabajo No 98, p 43-66 
silk route", which details the conceptual framework, areas for cooperation and cooperation mechanisms. ${ }^{3}$

At present, this initiative comprises not only one route but several, six terrestrial corridors and one maritime. Although it comprises numerous countries, as has already been mentioned, it is not a formally integrated economic area, since it has no common institutions, no definite deadlines for projects, as well as no "member" countries.

The six terrestrial corridors are:

i. China - Mongolia -Russia corridor ${ }^{4}$

ii. Eurasian corridor ${ }^{5}$

iii. China Central Asia and Western Asia corridor ${ }^{6}$

iv. China - Indochina Peninsula corridor ${ }^{7}$

v. China - Pakistan corridor ${ }^{8}$

National Development and Reform Commission, Ministry of Foreign Affairs, and Ministry of Commerce of the People's Republic of China (2015): Vision and Actions on Jointly Building Silk Road Economic Belt and 21st-Century Maritime Silk Road

4 At the September 2014 meeting of the Shanghai Cooperation Organization, it was agreed to work on the cooperation ties between the three countries to strengthen land and rail transport connections, as well as simplify customs procedures. A year later, the Joint Medium-Term Plan for the Trilateral Development of Cooperation between China, Russia and Mongolia was adopted. (Ramon-Berjano, C., 2016), p.61

5 This corridor links the coastal zone of China with Europe through the autonomous region of Xinjiang in western China, Kazakhstan, Russia, Belarus, Poland reaching Germany and other European countries

6 This corridor also crosses the Xinjiang Autonomous Region of China and connects with the railway systems of Central Asia - Kazakhstan, Kyrgyzstan, Tajikistan, Uzbekistan and Turkmenistan - as well as Iran and Turkey in Western Asia. A commitment to strengthen ties within the economic corridor among the 5 Central Asian countries was included in the joint statement at the China-Central Asia Cooperation Forum in June 2015. Previously this had been dealt with through bilateral agreements. Each of these countries, in turn, has its own development plans, which in turn have much in common with the economic belt proposed by China. (Ramon Berjano, C. 2016, p.62)

7 During the 5th Meeting of Leaders of Sub Regional Economic Cooperation of the Greater Mekong in December 2014 in Bangkok, several initiatives were proposed for the joint planning and construction of a transport network, as well as industrial cooperation projects and the promotion of projects that benefit sustainable economic development among the countries involved. Currently there are ongoing projects for the construction of several routes connecting this region, both by land and air. (Ramón Berjano, C. 2016, p.62)

8 The first time this corridor was mentioned was during Li Keqiang's visit to Pakistan in 2013. Plans have been extended and currently includes not only the creation of a corridor from Xinjiang to the port of Gwadar in southern Pakistan but a comprehensive long-term plan that includes the construction and renovation of highways, railways and pipelines, oil pipelines; airports, and a fiber optic network between the two countries. (Ramón Berjano, C. 2016, p.63) This corridor, better known by its acronym in English CPEC (China Pakistan Economic Corridor) along with the Eurasian, are keys within the initiative. On the other hand, this corridor between China and one of its great allies Pakistan, is a subject of controversy with India, since this corridor crosses the region of Kashmir. 
vi. Bangladesh - China - India - Myanmar corridor ${ }^{9}$

In addition to these six terrestrial corridors the initiative also includes a maritime corridor linking Chinese coastal areas with Europe via the South China Sea, Indian Ocean, Persian Gulf, Suez Canal and Mediterranean.

This initiative is being coordinated by the National Development and Reform Commission, the Ministry of Foreign Affairs and the Ministry of Commerce and its funding comes from the above-mentioned AIIB - which currently has 70 members ( 57 founding members ${ }^{10}$ ) and an initial capital of US $\$ 100$ billion - and the Silk Road Fund - with funds from the Chinese government, with an initial capital of US\$ 40 billion.

Figure 1. The land and sea corridors within the BRI

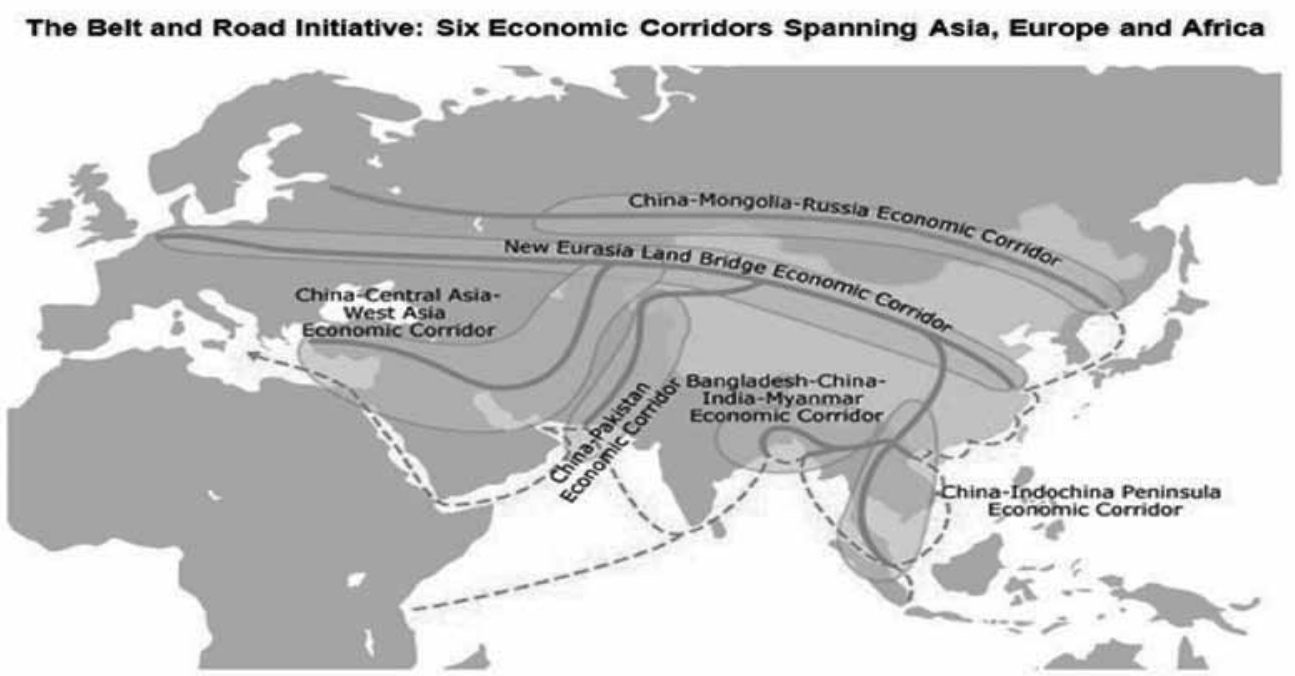

Source: Winter, T. (2016)

$9 \quad$ The first Joint Working Group on the Bangladesh-China-India-Myanmar economic corridor had its first meeting in the Chinese city of Kunming in 2013. In October 2016 Xi Jinping visited Bangladesh and Cambodia to deepen cooperation ties and strengthen this economic corridor. Cambodia signed more than 30 agreements, mostly related to infrastructure and industry. At the beginning of 2015, the China - Myanmar pipeline was inaugurated, which allows China not only to reduce the transport distance but also to diversify its dependence on imports across the Malacca Strait. (Ramón Berjano, C. 2016,p.63)

10 The founding members of the AIIB are: Australia, Austria, Azerbaijan, Bangladesh, Brazil, Brunei Darussalam, Cambodia, China, Denmark, Egypt, Finland, France, Georgia, Netherlands, Saudi Arabia, India, Indonesia, Iran, Iceland, Israel, Italy, Jordan, Kazakhstan, Kyrgyzstan, Laos, Luxembourg, Malaysia, Maldives, Malta, Mongolia, Myanmar, Nepal, New Zealand, Oman, Pakistan, Poland, Portugal, Qatar, United Kingdom, Russia, Singapore, South Africa, Sri Lanka, Sweden, Switzerland, Thailand, Tajikistan, Turkey, Uzbekistan and Vietnam. 


\section{International and Chinese Dimensions of the Initiative}

This initiative has two important and complementary dimensions, the international and domestic. Regarding the international dimension, it refers to the new positioning of China as a leading global actor and to the geopolitical dimension of Chinese leadership.As for the domestic dimension, this refers to Chinese domestic development, a long-term project that has already taken several decades since the process of reform and opening up in China in the late 1970 s and early 1980 s.

\subsection{International Dimension}

The BRI, through the connection of planned infrastructure, will allow the growth and economic development not only of China's neighboring countries in Central Asia, but will also have an impact on Russia, Belarus, Iran and even Turkey. The implications for European and the rest of the world economy of this strategy could completely change the global geopolitical map. China has signed memoranda of understanding with 50 countries and regional organizations related to the BRI. These include areas such as telecommunications, railway and construction companies of Chinese origin that have signed and initiated projects in different countries to improve connections as well as the construction of industrial parks and various other projects.

In this way, the initiative fulfils not only the objective of continuing and completing the step-by-step development process begun in the 1980s, as has already been mentioned, but also of continuing the insertion of China into the world economy, significantly impacting economies of the region and the rest of the world. Examples of this insertion are the railway lines that already connect China with Europe. In 2012, the first regular service from China to Europe was inaugurated, linking the Chongqing Municipality with the city of Duisburg in Germany, Kazakhstan, Belarus and Poland. This line links the two cities on a journey of more than $11,000 \mathrm{~km}$ in 16 days. In 2016, the record reached 40,000 containers transported and the goal is to reach 100,000 by 2020 . By the end of 2014 the line was extended to unite the coastal city of Yiwu China in Zhejiang Province with the city of Madrid in Spain, a journey of $13,000 \mathrm{~km}$ that takes place twice a week in trains that transport 40 containers. Currently these trains cover 39 routes joining 16 Chinese cities with 15 European ones. The last city to join this rail network was London, in the United Kingdom, with the train called "Eastern Wind" that united Yiwu with this city on January 1, 2017, transporting 34 containers through $12,000 \mathrm{~km}$ in only 16 days.

There are doubts about the feasibility and cost-effectiveness of these means of transport given that special containers are needed for low temperatures, there is an asymmetry in the number of products transported in each direction, 
the different size of the gauge which raises the cost, and the small number of containers and transport costs vis-a-vis shipping. However, the projects are still going ahead. ${ }^{11}$

In 1904, Sir Halford Mackinder defined Eurasia as the pivot region of the world. "Is not the "pivot region" of world politics that vast area of Eurasia that is inaccessible to ships, but which was formerly open to riders nomads, and is now about to be covered by a railway network?" 12 He affirmed that the nation that would dominate this "pivot region" would also become a world power. He considered that if China dominated this region, it would be unstoppable because "they would add an ocean front to the resources of the great continent, advantages that the occupants of the "pivot region" have not yet enjoyed."13 "Whoever rules the Continental Heart will dominate the World Island" and who "governs the World Island will dominate the world". ${ }^{4}$ A little over a century later, Mackinder's words resonate again with the BRI.

\subsection{Chinese National Development- New Roads to economic development}

China's economic development since the late 1970s has been known as the "ladder-step", since the objective was to open gradually to the world, or by steps. The Chinese provinces were grouped into three categories: east, central and west. In a first stage, preference was given to China's coastal regions (particularly the southern provinces), which were considered better able to implement the pilot reforms of the Special Economic Zones (SEZs) and be the recipients of foreign direct investment, since they were strategically located for those companies that wanted to enter China and for all future exports from China to the rest of the world. Within the framework of this strategy, these special economic zones, at an early stage, would be propagated along the coastal areas, thus becoming the "first step" of the Chinese development strategy. Once this first step had been developed, it would be moved to the "second step", that is the central area and then a third stage would be passed to the "third step", that is, the western area of China. Indeed, in subsequent stages, economic development gradually moved into the interior of the country in a process known as the "Go West" strategy that began in the late 1990s.

11 A container of 40 feet by sea takes $50 \%$ more time but costs $40 \%$ less (it is estimated that by sea the price is US $\$ 1500$ / container and it takes 35 days, whereas in the train the cost is US $\$ 2500$ / container but arrives in 18 days). On the other hand, each train can carry between 34 and 40 containers while 10,000 are transported by boat, which would be equivalent to 294 trains at an hour and half intervals for 17 consecutive days.

12 Mackinder, J. H. (1904): The Geographical Pivot of History, Geographical Journal, Vol. 23, No. 4

13 Ibid

$14 \quad$ Ibid

Vol. 15, № 3, 2018: 173-192 
As a result of this development process, three major development poles in coastal areas (or first step) can be mentioned - the Pearl River Delta, emblematic of the 1980s in the southern province of Guangdong (with Shenzhen at the top, and in particular its growing ties with the neighboring city of Hong Kong); the Yangtze River Delta, which characterized the growth of the Nineties (with Shanghai East - Pudong) and the Bohai Basin (which includes the two municipalities of Beijing and Tianjin). On the other hand, as a result of the "Go West" process (second step), the Chongqing cluster - the first non-coastal cluster was developed. Chongqing, formerly part of Sichuan Province and later elevated to the category of Municipality in 1997, a category to which Beijing, Tianjin and Shanghai belonged - today is a centre specialized in the production of laptops (30\% of the world production) and motorcycles (main producer in China) ${ }^{15}$. These four poles are shown on Map 2. This "Go West" strategy involved 12 western Chinese provinces whose total trade increased 9-fold since then, following a relocation of manufactures to the west of China. Both Chongqing and Chengdu (capital of Sichuan province) received labor that had previously left the coastal areas in the 1980s and 1990s. Companies such as Hewlett Packard expanded from Shanghai to Chongqing; and similarly, Foxconn from Shenzhen to Chengdu. Chongqing, along with the city of Chengdu, is estimated to be the most important economic center in western China in the next 20 years.

In 2004 this development campaign in western China was complemented by "Rise of Central China" where cities like Xi'an in Shaanxi Province (also in central China but north of Chongqing) were investment destinations. The aim is to turn this historic city into a regional growth pole for the western region, a kind of "West Shenzhen". Following several projects carried out in Xi'an and neighboring cities, during the 2000s the city's GDP increased more than 5 times and urban areas almost doubled in area. ${ }^{16}$

Finally, the BRI Initiative was announced in 2013, with central axis in the city of Xi'an, which, as mentioned above, was the starting point of the original silk route. As a national strategy, it is possible to follow the Chinese regional development, with emphasis on the areas of central and western China; as well

15 In 2014 Chongqing produced 61 million laptops, being the largest producer of laptops in the world - with an estimated production of one-third of the world total. It is estimated that $100 \%$ of Acer's production, $90 \%$ of Toshiba, $80 \%$ of Asus and $60 \%$ of Hewlett-Packard are produced in this municipality (China Daily, January 9, 2015). According to data from China Motor Rider (2015) Chongqing produces 12 million motorcycles and motors annually and in turn more than $40 \%$ of Chinese motorcycle exports are produced in more than 100 companies established in this municipality. (Ramón Berjano, C.,2016)

16 Among them in 2002 was announced the Xi'an integration project with the neighboring city of Xianyang, to create a high-tech industrial belt around these cities. In 2009, the State Council approved the project to accelerate growth and integration between XianXianyang and convert Xi'an and surrounding areas into a metropolis of 10 million people, becoming part of the so-called "Mega -cities "in China (Jaros (2013) and Ramón Berjano, C. (2016)). 
as allow an opening to the rest of the world not already through the coastal zones of the east of the country, but through the west of the country, reflating old trade routes.

Figure 2. The four regional development poles in China

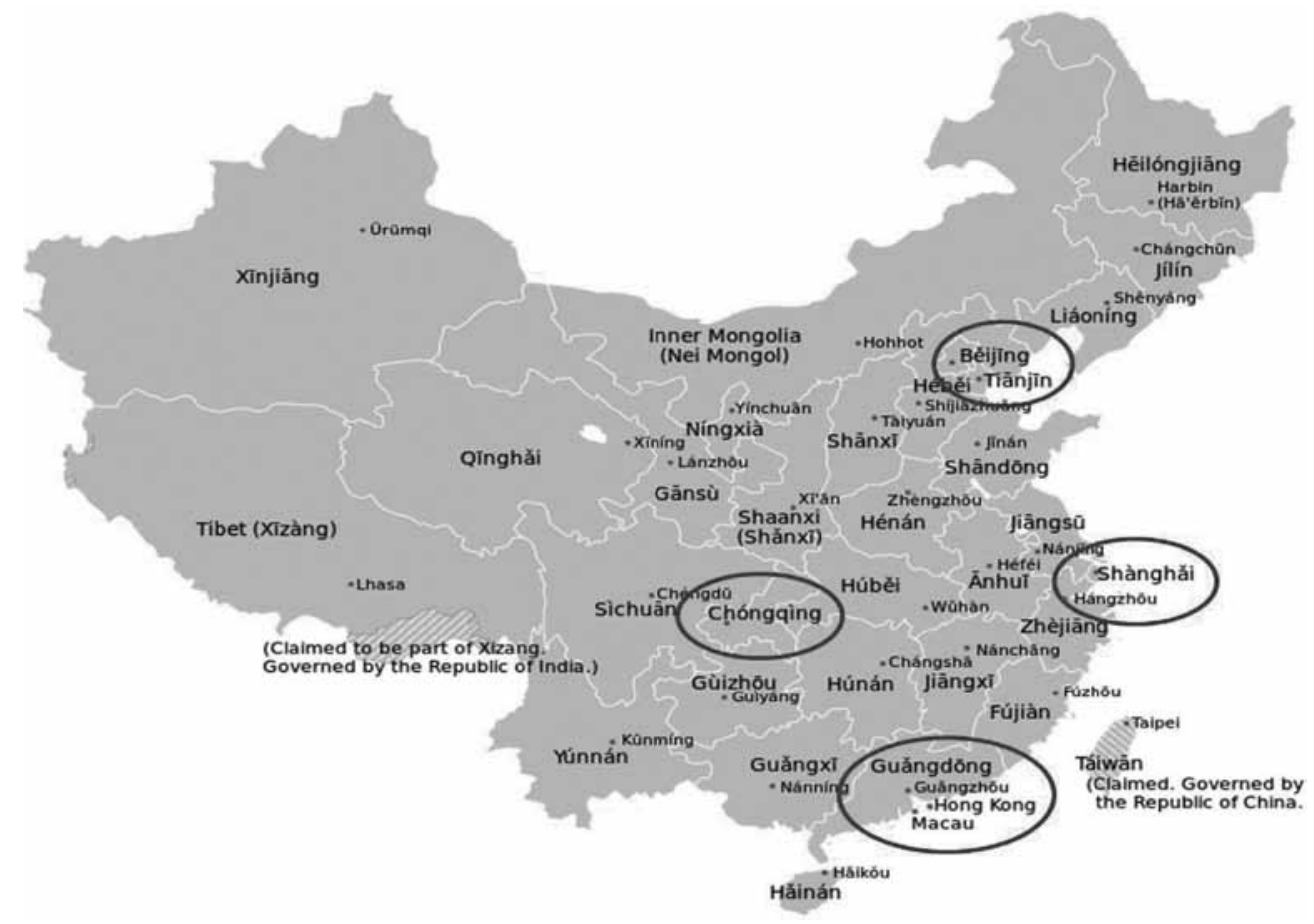

Source: the author's own

\section{Importance of the Xinjiang region in BRI}

To this end, like at the beginning of the reform and opening process, several special economic zones (SEZs) have also been established in recent times in the autonomous region of Xinjiang in the northwest of the country, which is of paramount importance within this BRI project. The importance of this region lies not only in the economic development of one of China's most remote and backward regions, but also in terms of security and internal stability. That is why this region has been designated as the core of the silk route initiative. It is the region that presents the most challenges in terms of regional development, internal domestic policy and international insertion.

Although the Autonomous Region of Xinjiang comprises 17\% of China's territory, it has less than $2 \%$ of its population. On the other hand, while $92 \%$ of 
China belongs to the Han ethnic group, in Xinjiang this ethnic group is only $39 \%$ of the total population, while $46 \%$ is the Uyghur ethnic group. The Xinjiang Autonomous Region has been designated core within the BRI, as it is an important link between China and Eurasian and Pakistani corridors. This region, in turn, has three corridors linking it to the most dynamic centers of China (the three coastal and Chongqing, seen in Map 2) with the terrestrial corridors (Maps 3 and 4).

The special economic zones of Xinjiang (Map 3), those of Urumqi, Kashgarand, Khorgas deserve special attention. Urumqi, the capital of the autonomous region, has an area of economic and technological development (created in 1994) and an area of export processing (2007). Despite being the most remote capital from Beijing, the city of Urumqi is now a dynamic center in western China, with flights linking it with different cities in central Asia and the Middle East. The trade fair "Urumqi Foreign Economic Relations and Trade Fair" has been established since 1992. Later on, in 2010, this trade fair was upgraded from a purely local in nature to a larger one to cover the entire Asian and European region, the "China-Eurasia Expo". Its sixth edition in 2016 covered an area of $140,000 \mathrm{~m}^{2}$ distributed in 14 pavilions and almost 7,000 stands.

Figure 3. Xinjiang Autonomous Region: its corridors and SEZs

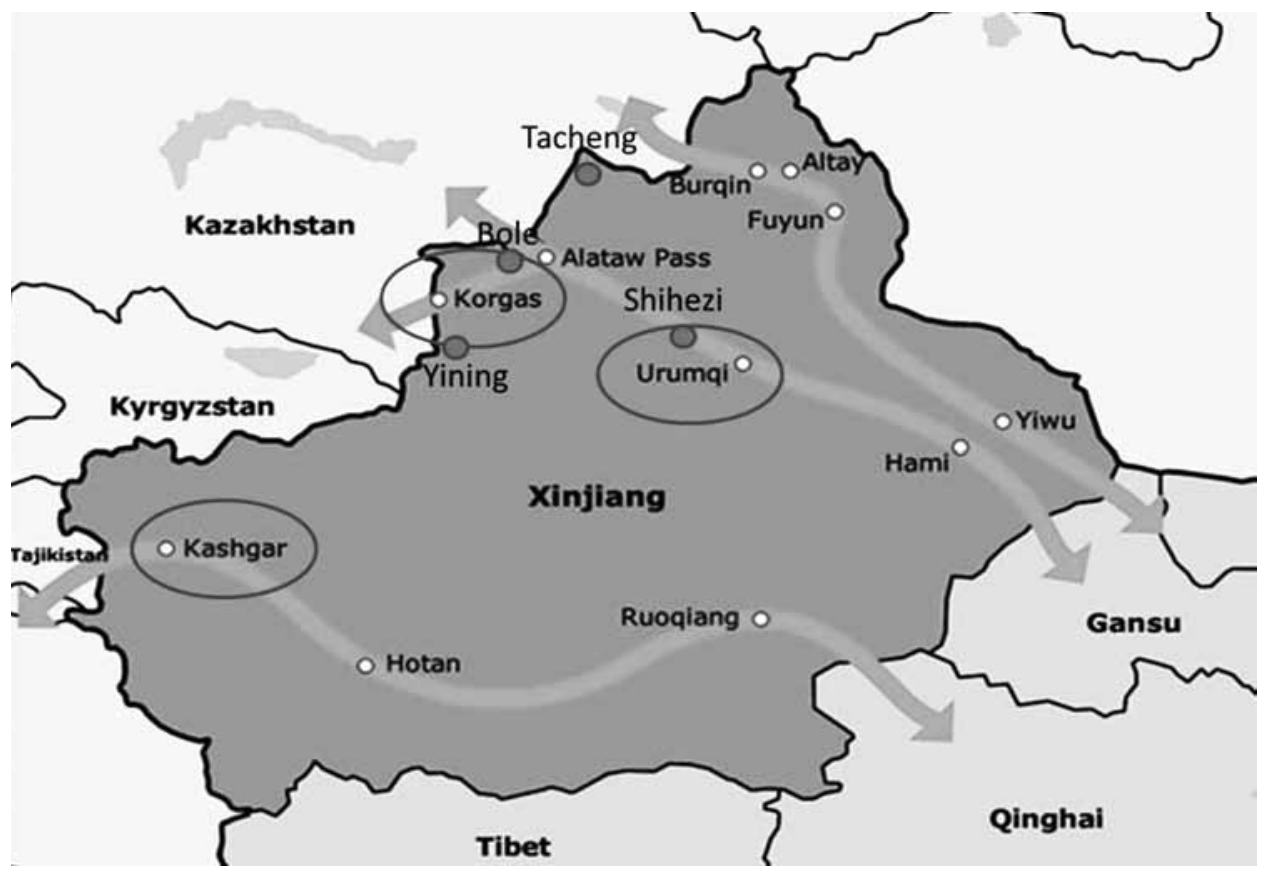

Source: The author's own base on HKTDC (2016) 
The city of Kashgar, formerly important trade post on the original silk route - and westernmost China city, almost $4400 \mathrm{~km}$ from the coast - was awarded the status of special aeconomic zone in 2010. Since its inception it has grown at a rate of $17 \%$ on average annually. Khorgas, another special area of economic development, created in 2014, attracted nearly two million traders in the year of its creation. It is the home of the China-Kazakhstan-Khorgas International Border Cooperation Centre; the Khorgas Free Trade Area (between both territories) and an export processing area. There are also several economic areas of border cooperation in the cities of Bole, Shihezi, Tacheng and Yining.

Although the geography of the region is complex, investment in infrastructure has increased in recent years and several trains link different cities, such as the line that since 2009 has been joining Urumqi and Khorgas via Yining, and since 2012 it has been possible to travel by train from Khorgas to the Zhetygen terminal near Almaty in Kazakhstan. It is expected that up to 15 million tons of cargo will circulate annually, doubling in the future.

Map 4 shows the three corridors that cross the Xinjiang Autonomous Region and the way they unite the China's coastal zones, namely the three major clusters of eastern China - the Bohai Basin to the north, Yangtze in the middle and Pearl River Delta to the south - with three of the great corridors of the BRI - that of Mongolia, the Eurasian and the Pakistan corridor.

Figure 4. Xinjiang as a link between coastal clusters and economic corridors

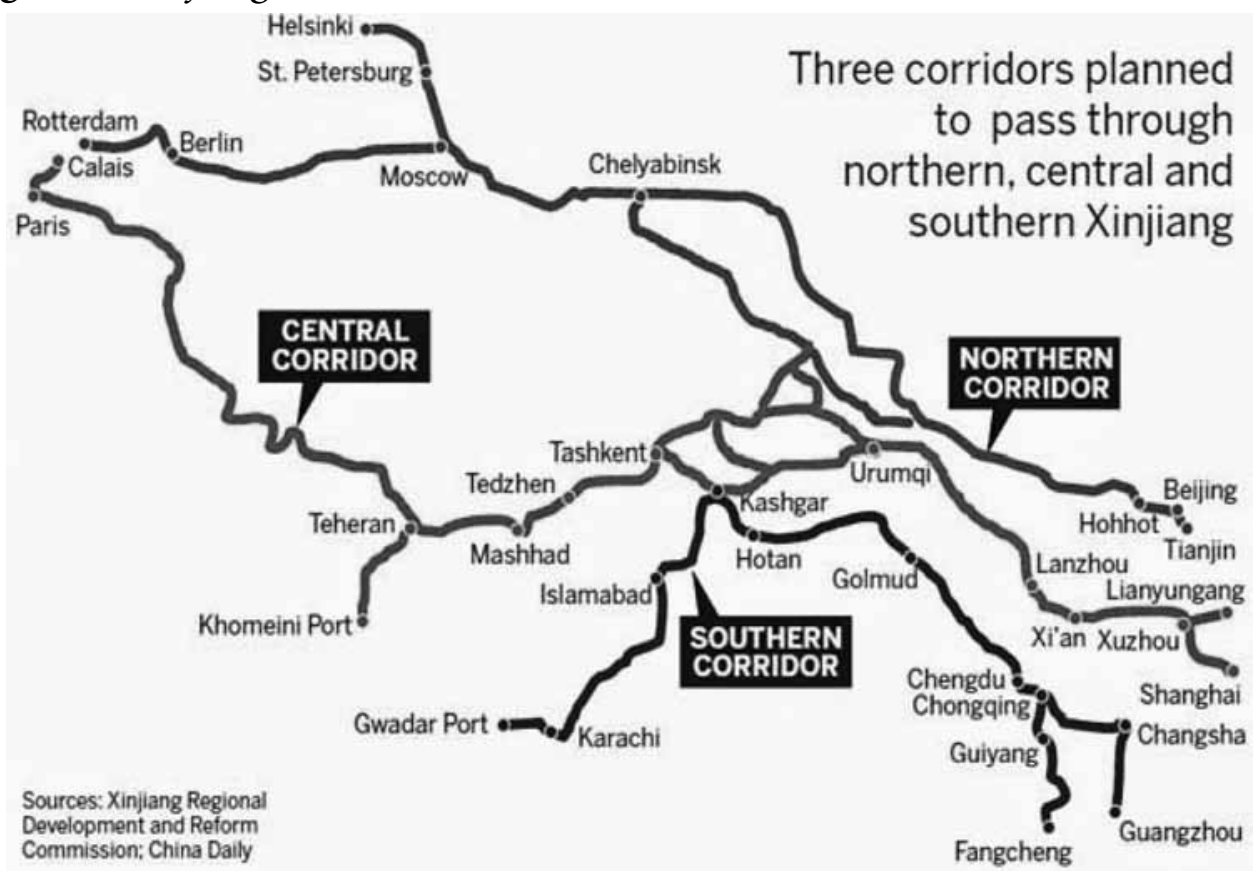

Source: Cui, J. (2014)

Vol. 15, № 3, 2018: 173-192 
It is observed that although the nucleus of this initiative is in Xinjiang by the Chinese side, a vital part of the same occurs in Central Asia. Integration with neighboring countries, in particular the five Central Asian countries, is therefore vital. In fact the relations between China and these countries have improved significantly, as well as the ease of doing business in these countries. In the crossborder trade ranking, the indices from 2013 to 2016 show notable improvements, particularly in the case of Kyrgyzstan and Kazakhstan. Trade between China and Central Asian countries has increased in the last decade, as well as investment in these countries, particularly in Kazakhstan and Kyrgyzstan. China's investments in these countries in the decade of 2004-2014 increased rapidly. As shown in Graph 2, the most important destination is Kazakhstan (52.9\%) followed by Kyrgyzstan (21.8\%), Uzbekistan (11.1\%), Tajikistan (10.3\%) and Turkmenistan (4\%). Connections between China and these countries have also improved with several daily flights between China and Central Asia. ${ }^{17}$

In fact, China became a larger trading partner for these countries than Russia, traditionally its largest trading partner (Graph 1). Much of China's trade with Central Asia occurs through Xinjiang, about 44\% (although many of these products are re-exports from coastal provinces). It is estimated that more than half (55\%) of total trade in Xinjiang occurs with Central Asian countries. Moreover, 40, 75 and 74\% of China's total trade with Kazakhstan, Kyrgyzstan and Tajikistan respectively occurs through the Xinjiang Autonomous Region.

The development of western China is therefore vital to this strategy. On the other hand, the gas and coal reserves and lower costs than in the coastal provinces are expected to attract a rapid investment in this region. The closer ties of this region with its neighboring countries, both in Central Asia, Mongolia, the Middle East and Europe, will change the commercial and economic configuration of this region. In spite of this, the strategy also carries some risks, the greater of them being related to the social stability of the more western regions of China and its neighbors. Given the scale of this strategy, it is not at all random that most of the efforts of the national government are devoted to this region.

Hong Kong Trade and Development Council (2015) 
Graph 1. Trade of central Asian countries with Russia and China Trade with central Asian countries

Merchandise exports and imports, sum over previous 12 months ( $\$ b n)$

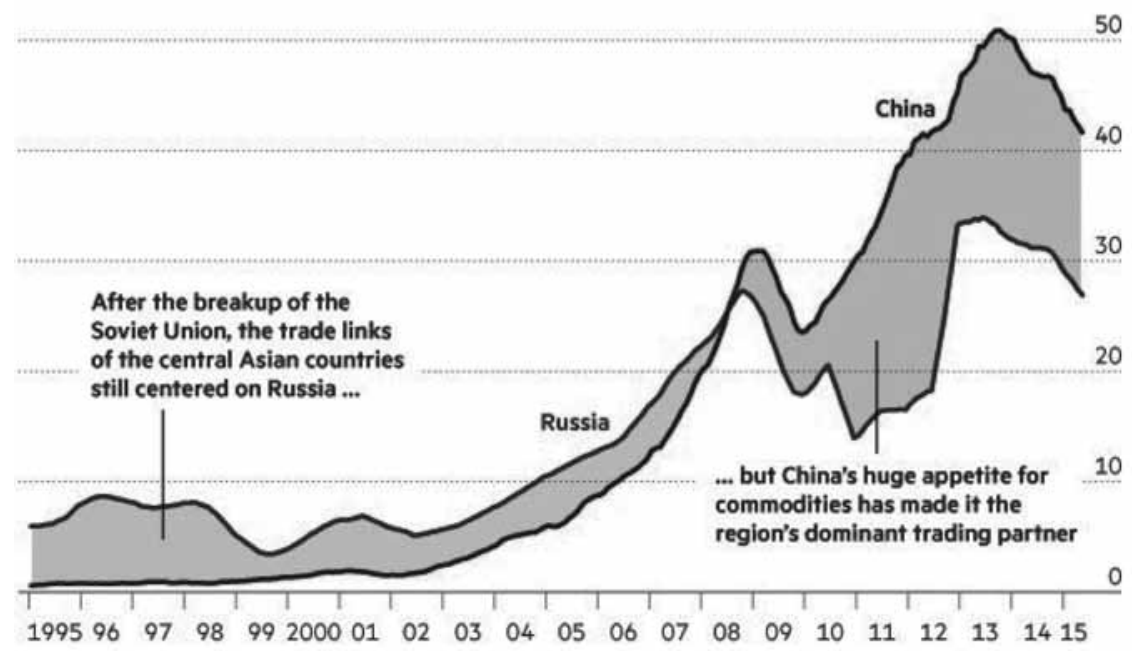

Source: Rogan, A. (2016)

Graph 2. Chinese Investment in Central Asia

\section{China's Stock of Outward Direct Investment to Central Asia}

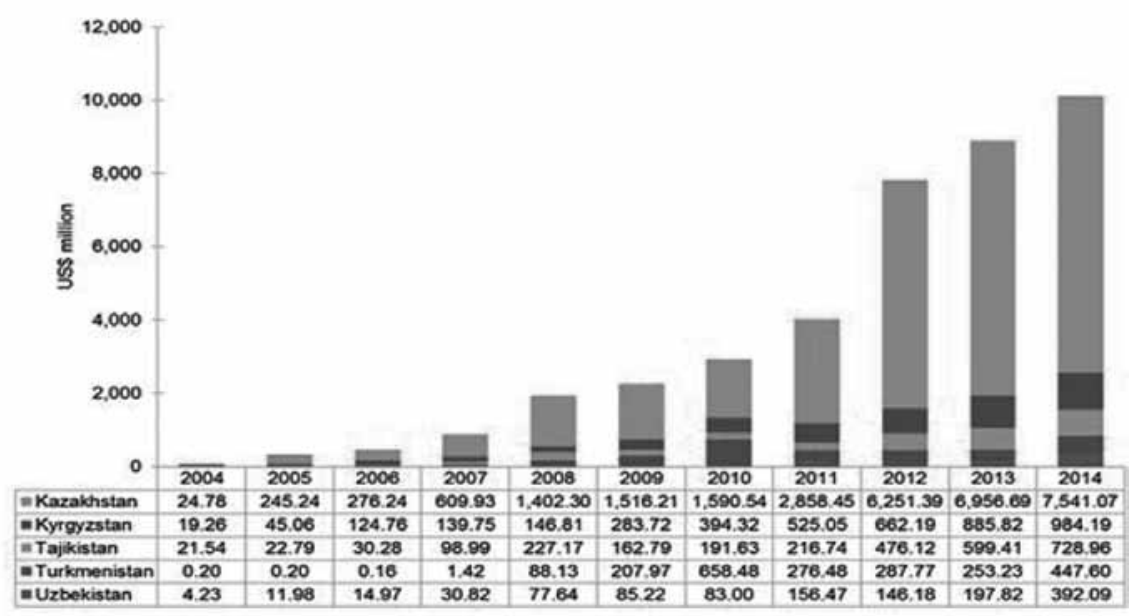

Source: Statistical Bubletin of China's Outward Foreign Direct Investment

Source: HKTDC (2015) 


\section{What are benefits and possibilities/opportunities for Latin America from BRI}

Over the last couple of years since the announcements by $\mathrm{Xi}$ Jinping of the Belt and Road Initiative, infrastructure investment has increased massively, not only within the region covered by the BRI but also further away, raising interest for this initiative in the areas such as Latin America and Africa. Although geographically not part of the initiative and despite the long distances involved, the global connectivity, trade and development project has certainly captured the attention on the other side of the globe. Latin America is a region that has a significant shortage in infrastructure investment, particularly the type of infrastructure that aids connectivity and the development of an internal market as well as an export-oriented connectivity. Last year, at the Belt and Road Forum held in Beijing in May 2017, two countries from Latin America where present Argentina and Chile. Both countries have now applied for membership to the AIIB. This is a significant signal that these two countries, as well as the other 4 that are already members or applied to become so, consider this initiative to be relevant for the region. Investments in infrastructure and connectivity within Latin America would be essential for inserting these countries into local, regional and international value chains.

As mentioned, Latin America does not belong to any of the six land economic corridors or the maritime corridor. However, that does not mean that it has not become interested in its potential implications, in terms of trade and investment. Regarding trade, the potential insertion of our products into the BRI offers Latin America many opportunities. New demands, preferences and niche market opportunities arise from the integration of markets along the Belt and the Road, and making the most of these is therefore essential for the region. The processes in China as well as in the rest of Asia that include increasing urbanization, more middle classes, and the emergence of upper classes bring along fundamental changes in the patterns of consumption such as online retailing. This increased from US $\$ 1.230$ billionto US $\$ 3.970$ billionfrom 2012 to 2017, which implies an annual growth rate of $34 \%$. It is estimated that the current number of buyers online is about 500 million, double the number relative to only 5 years ago. ${ }^{18}$

Telephone sales have increased behind the success of companies such as Alibaba and Ten cent that share about $90 \%$ of the online market, the former with $54 \%$. These sales are equivalent to 90 times the online mobile phone purchases in the United States. During November $11^{\text {th }}$, usually known in china as "single's day", which is the main day ofonline sales in China, Alibaba total sales in 24 hours were U\$18.000 million (six times as much as what was sold in the three days of the US equivalent "Black Friday" or alternatively the annual online total

18 China Internet Watch (2017): China's online shoppers grew to 500M in 2017 in 5 years 
sales in Brazil $)^{19}$. In November 2017, total sales reached a new record of over US $\$ 24.000$ million. In only 4 hours, 1,6 million Argentine shrimps were sold. ${ }^{20}$

Therefore, innovation, strategic thinking and long-term vision will be vital to make the most of this Chinese-led project for the Latin American region. Having a clear idea and strategy as to what projects would be most beneficial for the region is therefore crucial: investments that not only aim to increase connectivity with overseas markets - mainly exports to Asia - but also serve to fulfill the long-term objectives in Latin America regarding local and regional development, strengthening of domestic markets, local efficiency and ultimately aid in poverty reduction. Chinese experience in regional development and infrastructure building can therefore be of high significance for our region.

As mentioned above, the Silk Road Initiative, with its center in the Xinjiang Autonomous Region in particular has generated a lot of investments in infrastructure, in special economic zones and in incentives for the relocation of production to this area of the country. The goal is for theXinjiang region to become a dynamic center in western China, just as in the 1980s the coastal areas were. While in the eighties China left the world through the Special Economic Zones in the coastal strip of the country the initiative of the silk route in its terrestrial corridors is to go out into the world through the most economically backward regions of the center-west of China, privileging the area of Xinjiang and its links with Central Asia. Taking into account this growth potential in this region of northwestern China, in addition to the issue of scale - many Chinese provinces have population size equal to the entire countries-we consider the possibilities for an exchange between this region and Argentina to be relevant. Looking for niche markets should be a vital strategy for countries such as Argentina and the rest of Latin America in order to achieve a much more balanced relation with China. In particular, Xinjiang comprises $17 \%$ of the Chinese territory, but does not reach $2 \%$ of its population. In fact, its capital, Urumqi, has 3 and a half million inhabitants which makes it a medium-sized city within China. However, although it is a small city by Chinese standards, the population of this city is equivalent to the total population of Argentina's neighboring country, Uruguay. Despite Xinjiang having a GDP lower than Chinese national average, the same trends are observed as in other areas of the country - income growth, changing preferences and new trends such as increased consumption of beef, seafood in particular shrimp and prawns, olive oil, dried fruits and wine. The size of this region, as well as its strategic location within the Silk Road Initiative and direct connections with Central Asia, the Middle East and Europe, putit in a place of importance when it comes to the early detection of niche markets. An example of this is the niche of halal products for Muslim populations, with $2 \%$

\footnotetext{
19 Newley Purnell (2017): Alibaba and Tencent Set Fast Pace in Mobile-Payments Race

20 Infocampo (2017):Argentina presente en el mayor evento de promoción online en China
} 
of the Chinese population being Muslim and most of it concentrated in Xinjiang Region ( 28 million consumers, about $40 \%$ of the total population of Argentina).

Strengthening links and studying the possibilities of emerging niches and new demands in this region of western China, as well as in bordering countries that will experience similar changes in terms of income snow, urbanization and changes in demand, will be key to change the international insertion and add value to our exports.

\section{Conclusion}

Understanding this initiative and reflecting on how it can affect Latin America is therefore crucial. Although Latin America and Argentina in particular are not explicitly included in the initiative, this project affects us as well as the rest of the world economy. On the one hand, the immediate effects refer to the greater connectivity between China and its neighbors that belong explicitly to the Initiative. As trade between China and these countries increases, so do the possibilities for Latin American products to be replaced by those products of neighboring countries. The pattern of trade between China and the countries of Central Asia follows patterns similar to those of Latin America and Africa, i.e. raw materials for manufactured goods. Another immediate effect, which also originates in China's greater exchange with its neighbors, is the emergence of new opportunities along these new routes, with new demands, tastes and preferences, as well as market niches in which Latin American products could find new destinations. Finally, increased links between China and Europe also present Latin America with new opportunities, since an arrival to Asia could occur not only via the Pacific but also via the Atlantic.

On the other hand, and thinking in the mid- and long-term, the BRI can benefit Latin America in terms of infrastructure projects. Infrastructure investment is an area that the Latin American region clearly needs. For this, membership in the AIIB (Asian Infrastructure and Investment Bank) is vital. From Latin America, only Brazil belonged to it as a founding member, but now other five Latin American countries are its members as well (Peru, Venezuela, Chile, Bolivia and Argentina). Considering all the infrastructure projects in which China has participated or has expressed an intention to participate, it can be seen that the BRI has the potential to be a truly global project. These projects include the railroad across Africa linking Angola, Congo, Zambia and Tanzania; the tunnel project in the Bering Strait; the trans-Amazonian railway that would link Brazil with Peru; the Canal de Nicaragua, the Kra Canal in Thailand; the high-speed train in Mexico; etc. Some of these projects, although far from being implemented or even approved, show a global connectivity initiative with China as the undisputed protagonist of this new global system. Undoubtedly, more 
than ever, Latin America needs to identify the options for both the short and the long term if it wants to put together a strategy that is mutually beneficial.

\section{Literature}

- Chin, H. and W.He (2016):The Belt and Road Initiative: 65 Countries and Beyond, May 2016, in Global Sourcing Fung Business Intelligence Centre, https://www.fbicgroup.com/sites/default/files/B\%26R_Initiative_65_ Countries_and_Beyond.pdf?ct $=\mathrm{t}$ (The_Belt_and_Road_Initiative_65_ Countrie5_13_2016)\&mc_cid=9e6c27e9ac\&mc_eid=70782f0ae4

- China-Britain Business Council (2015): One Belt One Road, a role for UK companies in developing China's new initiative, http://www.cbbc.org/sectors/ one-belt,-one-road/

- China Internet Watch (2017) China's online shoppers grew to 500M in 2017 in 5 years, 24 October 2017, https://www.chinainternetwatch.com/22671/ ecommerce-overview-2013-2017/\#ixzz50svxCRm4

- Centre for European Reform (2017): The EU, the Eurasian Economic Union and One Belt, One Road: Can they work together?, https://issuu.com/ centreforeuropeanreform/docs/pb_eurasian_ib_16.3.17_0

- Cui, J., (2014): China studying new Silk Road rail link to Pakistan, China Daily, June 28, 2014, http://usa.chinadaily.com.cn/business/2014-06/28/ content_17621848.htm

- Holland, T. (2017): Puffing across the 'one belt one road'rail route to nowhere, South China Morning Post, http://www.scmp.com/week-asia/business/ article/2089507/puffing-across-one-belt-one-road-rail-route-nowhere

- Hong Kong Trade and Development Council(2015):An Overview of Central Asian Markets on the Silk Road Economic Belt, http://economistspick-research.hktdc.com/business-news/article/Research-Articles/ An-Overview-of-Central-Asian-Markets-on-the-Silk-Road-Economic-Belt/ rp/en/1/1X000000/1X0A4C4W.htm

- Hong Kong Trade Development Council Research(2016):Xinjiang: a Core Component of the Belt and Road, http://economists-pick-research. hktdc.com/business-news/article/Research-Articles/Xinjiang-A-CoreComponent-of-Belt-and-Road/rp/en/1/1X000000/1X0A5D5S.htm

- Hong Kong Trade Development Council Research (2017):Belt and Road Initiative, http://china-trade-research.hktdc.com/business-news/ article/The-Belt-and-Road-Initiative/The-Belt-and-Road-Initiative/obor/ en/1/1X000000/1X0A36B7.htm

- Hsu, S. (2015):Economic Zones and Infrastructure on China s Silk Road, The Diplomat, January 212015 
- Infocampo (2017): Argentina presente en el mayor evento de promoción online en China November 16, 2017 http://www.infocampo.com.ar/ argentina-presente-en-el-mayor-evento-de-promocion-online-en-china/

- Jaros, K. (2013): Forging a Metropolis: State led Urban Development in $X i$ 'an China, Fall 2013, Volume 28, Number 1, http://wcfia.harvard.edu/ publications/centerpiece/fall2013/feature_jaros

- Mackinder, J. H. (1904): The Geographical Pivot of History, Geographical Journal, Vol. 23, No. 4 (Apr., 1904)

- National Development and Reform Commission, Ministry of Foreign Affairs, and Ministry of Commerce of the People's Republic of China, (2015), Vision and Actions on Jointly Building Silk Road Economic Belt and 21st-Century Maritime Silk Road, March 2015 http://en.ndrc.gov.cn/newsrelease/201503/t20150330_669367.html

- Newley Purnell (2017): Alibaba and Tencent Set Fast Pace in MobilePayments Race, 22 September 2017, https://www.wsj.com/articles/alibabaand-tencent-set-fast-pace-in-mobile-payments-race-1506072602

- Ramon-Berjano (2016):La iniciativa "Un cinturón, un camino" y el desarrollo del oeste de China: Impactos domésticos e internacionales, CARI, Documento de Trabajo No 98, P:43-66 in China En 2016 Reforma Política, Programas de Desarrollo e Inserción Económica Internacional, http://www.cari.org.ar/pdf/ dt98.pdf

- Rippa, A, (2013):Kashgar on the move, The Diplomat, October 142013

- Rogan, A. (2016):Is Central Asia in Russia's or China's Backyard?, Russia Supply Chain, January 12 2016, http://www.russiasupp, lychain.com/ is-central-Asia-in-Russia-or-chinas-backyard/

- Stratfor (2013):Chinas ambitions in Xinjiang and central Asia: Part 1, https:// worldview.stratfor.com/article/chinas-ambitions-xinjiang-and-central-asiapart-1

- Stratfor (2013): Chinas ambitions in Xinjiang and central Asia: Part 2, https:// worldview.stratfor.com/article/chinas-ambitions-xinjiang-and-central-asiapart-2

- Winter, T. (2016):One belt, one road, one heritage: cultural diplomacy and the silk road, The Diplomat March 292016

- Wood Mackenzie (2016):China's new superhighway to alter energy trade, https://www.woodmac.com/analysis/china-energy-trade 


\section{“POJAS I PUT” INICIJATIVA: INFRASTRUKTURA, INVESTICIJE I MOGUĆNOSTI ZA LATINSKU AMERIKU}

Inicijativa "Jedan pojas, Jedan put” koju je Kina predložila 2013. godine je nesumnjivo najambiciozniji projekat povezivanja u današnje vreme. Ona je od ogromnog značaja za trgovinu, kulturnu razmenu i izgradnju i razvoj infrastrukture. Ovaj rad opisuje ovu inicijativu kroz njene različite ciljeve - ne samo kao poslednji deo kineske strategije ekonomskog razvoja koja je započela u istočnim regionima osamdesetih godina prošlog veka, već $i$ kao geopolitički i međunarodni projekat koji naglašava novu ulogu Kine u svetu. Iako Latinska Amerika nije geografski deo ove inicijative onako kako je ona danas predstavljena, to ne znači da implikacije i mogućnosti ovog projekta nisu važne i za ovaj region.

Ključne reči: Inicijativa "Jedan pojas, Jedan put", Latinska Amerika, investicije, Autonomni region Ksinđang, ekonomski koridori. 